UDC 618.333. - $06+616-005.6$

DOI: 10.32345/USMYJ.3(111).2019.21-28

\title{
Котенок Антоніна
}

Асистент кафедри акушерства і гінекології № 3

НМУ імені О.О.Богомольця, Україна

\section{Гичка Назарій}

Доцент кафедри акушерства і гінекології №3

НМУ імені О.О.Богомольця, Україна

\section{Бенюк Василь}

Професор, д.мед.наук, завідувач кафедри акушерства і гінекології №3 НМУ імені О.О.Богомольця, Україна

\section{ПАТОГЕНЕТИЧНА ЗНАЧИМІСТЬ ВИЯВЛЕННЯ ПОРУШЕНЬ В СИСТЕМІ ГЕМОСТАЗУ ДЛЯ ДІАГНОСТИКИ ТА ПРОФІЛАКТИКИ ТРОМБОТИЧНИХ УСКЛАДНЕНЬ У ЖІНОК 3 АНТЕНАТАЛЬНОЮ ЗАГИБЕЛЛЮ ПЛОДА}

\begin{abstract}
Анотація. Стаття узагальнює аргументи та контраргументи в межах наукової дискусії з питання діагностики та профілактики порушень в системі гемостазу у жінок з антенатальною загибеллю плода. Основною метою даного дослідження є вивчення зміни системи гемостазу у вагітних з антенатальною загибеллю плода, а саме оцінка особливостей прокоагулянтної, антикоагулянтної та фібринолітичної ланок системи гемостазу у жінок з антенатальною загибеллю плода. Систематизація літературних джерел та підходів до проблеми гемостазіологічних порушень при антенатальній загибелі плода дає змогу підтвердити важливість даного питання, обьрунтовано оиінювати ризики під час вагітності у кожної конкретної жінки та, в периу чергу проводити профілактику виникнення даного ускладнення. В даній статті надані результати ретроспективного дослідження індивідуальних карт вагітних та історій пологів вагітних з антенатальною загибеллю плода та бізіологічною вагітністю в період з 2016 - 2018 роки. Актуальність дослідження даної патології полягає у тому, щзо кожна n'ята жінка репродуктивного віку стикається з такою проблемою, як перинатальні втрати. У структурі перинатальних втрат особливе місце посідає антенатальна загибель плода, що може призводити до розвитку синдрому втрати плода, ДВЗ-синдрому, інфекційних ускладнень у матері та непліддя чи суббертильності у майбутньому, що виілому негативно впливає на репродуктивний потенціал нації. В процесі роботи нами оцінювались такі показниками коагулограми як: протромбіновий індекс, тромбіновий час, активований парціальний тромбіновий час, розчинні бібрин мономерні комплекси, фібриноген плазми, антитромбін III та протеїн С.

Встановлено, що для вагітних з антенатальною загибеллю плода характерним $\epsilon$ підвищення згортаючої активності крові на фоні пригнічення антикоагулянтної та фбібринолітичної ланок гемостазу. Визначення активності антитромбіну ІІІ інбормує
\end{abstract}

Cite as: Kotenok A., Hychka N., Beniuk V. The pathogenetic significance of hemostatic disorders detection for the diagnostics and prevention of thrombotic complications in women with antenatal fetal death.

Ukrainian scientific medical youth journal, issue, 3(111), 2019. DOI: 10.32345/USMYJ.3(111).2019.21-28 
про стан антикоагуляційної системи організму та надає можливість коригувати лікування антикоагулянтними препаратами прямої діі. Показники коагулограми не можуть повністю відобразити стан гемостазу під час вагітності, тому пошук нових методів ранньої діагностики дисбалансу в системі гемостазу під час вагітності залишається актуальним і на даному етапі. Дані дослідження можуть бути корисними акушерам-гінекологам, особливо в жіночій консультації для формування групи ризику вагітних та проведення профілактичних заходів з метою попередження антенатальної загибелі плода.

Ключові слова. Антенатальна загибель плода, гемостаз, ендотелій, тромбофілія, фактори згортатання крові.

Вступ. В сучасному акушеррстві провідне місце серед найактуальніших проблем займає мертвонародження. Кожна п’ята жінка репродуктивного віку стикається з такою проблемою, як пренатальна втрата. В структурі перинатальних втрат виділяють: штучні аборти, самовільні викидні, мертвонародження, неонатальну смертність. Серед порушень репродуктивної функції у жінок особливе місце посідає внутрішньоутробна загибель плода. Затримка загиблого плода в матці негативно позначається на подальшій репродуктивній функції жінки, загрожуючи її здоров’ю та життю, що свідчить не тільки про медичну, але й про соціальну значимість проблеми (Р.М. Міцода та ін, 2015р.). Вагітність характеризується низкою адаптаційних змін, що стосуються практично всіх життєво важливих органів і систем в організмі жінки. Найбільш виразні відхилення на межі з патологією спостерігаються у системі гемостазу. Фізіологічно збільшується об'єм циркулюючої крові переважно за рахунок плазми, що пов'язано з посиленим ростом матки та збільшеною потребою в нутрієнтах під час вагітності, та як наслідок - зменшення формених елементів та альбуміну за рахунок гемодилюції. До основних змін гемостазу під час вагітності відносять збільшення тромбоцитарної активності, посилення прокоагулянтних властивостей ендотелію, збільшення вмісту факторів згортання крові, зниження антикоагулянтної активності. Ці зміни під час вагітності в згортаючій системі крові, з одного боку, підвищують ризик виникнення тромботичних та геморагічних ускладнень, а з іншого - зміни агрегатного стану крові можуть ускладнити будь-який інший патологічний стан під час вагітності. Головними показниками гемостазу, що змінюються під час вагітності є: активований частковий тромбоплатичний час (АЧТЧ), його норма складає 25-35 сек. Підвищений рівень АЧТЧ, може вказувати на схильність до кровотечі. Знижені показники можуть вказувати на першу фазу ДВС-синдрому; тромбоз і тромбоемболії. Тромбіновий час (ТЧ) - характеризує останній етап згортання крові, норма - 10,5-18 сек. Протромбіновий індекс (ПІ) - відображає якість згортання крові, його норма - від 80\% до 150\% (Чонко О.Ю та ін., 2018). Фібриноген - це безбарвний білок, класу $\beta$-глобулінів, в крові він перебуває в розчиненому стані, але під впливом тромбіну і фактора XIIIa перетворюється на нерозчинний фібрин - основу згустку, який згодом утворює тромб, завершуючи процес згортання крові. Його норма 2-4 г/л, в III триместрі вагітності до 6 г/л. Антитромбін III - при його зниженні збільшується ризик тромбоутворення, а при підвищенні збільшується ризик післяпологової кровотечі (Долгов В.В. та ін.,2006р.). Референтні 
значення показників системи гемостазу представвлені в таблиці. 1.

Значна увага дослідників, в наш час, приділяється спадковим тромбофіліям. Відсоток виявлення яких значно зріс завдяки сучасним широкодоступним діагностичним технологгіям. Такий стан може бути пов'язаний $з$ дефіцитом інгібіторів згортання або з варіантами генів, що призводять до гіперкоагуляційної настороженості. Варіантами генів, що часто пов'язані із синдромом втрати плода, являються протромбін G20210A та/або фактор V Лейден (Ridker P. M et al.,1998). Дослідження «випадок-контроль», що проводили Ridker та ін., 2009 вказують на підвищення розповсюдження мутації фактору Лейдена у жінок із синдромом втрати плода. Фактор V Лейдена був ідентифікований як фактор ризику виникнення антенатальної загибелі плода (Goodman C.S. et al., 2006). Також дефiцит інгібіторів згортання, таких як білок $\mathrm{S}$, білок C i/aбо антитромбін, був чітко пов'язаний із пренатальними втратами 3 1996 року. Також автори звертають увагу на варіант мутації гена PAI-1 4G/5G, що може бути повязаним з гіпофізбринолізом i, таким чином, 3 гіперколулюючими станами (Sanson B.J. et al, 1996).

До набутої форми тромбофілії відносять антифосфоліпідний синдром. Антифосфоліпідний синдром являєтся аутоімуним захворюванням, при якому антифонсфоліпідні антитіла (антикардиоліпінові антитіла та вовчаковий коагулянт) взаємодіють з білками, що зв'язуються з аніоновими фосфоліпідами на

Таблиця 1. Зміни в системі гемостазу під час фізіологічної вагітності (Куликов А. В. та інш., 2016 р.)

\begin{tabular}{|c|c|c|}
\hline Компоненти & Поза вагітністю & Під час вагітності \\
\hline Фібриноген & $2-4,5$ г/л & $4-6,5$ г\л \\
\hline Тромбоцити & $150-350 \times 10^{9} /$ л & Не змінюється \\
\hline Компоненти & Поза вагітністю & Під час вагітності \\
\hline РФМК & $3.0-4.5 \mathrm{мг} / 100 \mathrm{M} \pi$ & Дещо підвищується \\
\hline Фактор II & $75-125 \%$ & $100-125 \%$ \\
\hline Фактор V & $75-125 \%$ & $100-150 \%$ \\
\hline Фактор VII & $75-125 \%$ & $150-250 \%$ \\
\hline Фактор VIII & $75-150 \%$ & $200-500 \%$ \\
\hline Фактор IX & $75-125 \%$ & $100-150 \%$ \\
\hline Фактор X & $75-125 \%$ & $150-250 \%$ \\
\hline Фактор XII & $75-125 \%$ & $100-200 \%$ \\
\hline Фактор XIII & $75-125 \%$ & $35-75 \%$ \\
\hline D-димер & Менше 0,5 мг/л & $0,13-1,7$ мг/л \\
\hline Тканинний активатор плазміногена (ТРА) & $1,6-13$ мкг/л & 3,3-9,2 мкг/л \\
\hline Інгібітори активатора плазміногкна 1, 2 (PAI-1, PAI-2) & $100 \%$ & Збільшується \\
\hline Фактор Віллебранда & $100 \%$ & Збільшується \\
\hline Протеїн S & $100 \%$ & Зменшується \\
\hline Протеїн C & $100 \%$ & Не змінюється \\
\hline Антитромбін III & $80-130 \%$ & Не змінюється \\
\hline
\end{tabular}


плазматичних мембранах. При цьому стані виникає активація системи згортання крові: підвищується схильність до розвитку тромбозів (антифосфоліпідні антитіла індукують прокоагулятивний стан, оскільки IgG-фракція у позитивних на вовчаковий антикоагулянт (ВА) пацієнтів суттєво підвищує синтез тромбоксану порівняно з нормальним IgG, а також антифосфоліпідні титіла здатні заміщувати анексин V (антикоагулятивний білок) на клітинах трофобласту та ендотелію, ативуючи каскад коагуляції: змінюють експрессію аніонних ліпідів на мембранах та індукують апоптоз ендотеліальних клітин пупкових вен), призводять до виникнення дефектів плацентації. Зв'язуючись із клітинами трофобласту, антифосфоліпідні антитіла викликають пряме пошкодження клітин трофобласту, та цим самим, спричиняють апоптоз, пригнічують проліферацію та формування синцитію, зменшують синтез хоріонічного гонадотропіну, спричиняють дефектну плацентацію, а $\beta 2$-глікопротеїн-1-залежні антитіла суттєво інгібують утворення трофобласту. В акушерській практиці вищезазначене може бути пов'язане з патологією плаценти, що в наступному являється однією з патогенетичної причини виникнення антенатальної загибелі плода (Triplett D.A. et al, 2002; X.О. Ліщук-Якимович,. 2016).

Не менш важливим компотнентом ланки гемостазу $є$ ендотелій судин. Клітини ендотелію продукують цілий ряд біологічно активних речовин, таких як, на приклад, оксид азоту. Він викликає розслаблення гладких міоцитів, що зумовлює цим розширення судин. Ендоеліни, мають вазоконстрикторну дію та підвищують проникність судинної стінки, що супроводжується запальними реакціями. Також простацикліни та тромбомодуліни, виділені судинним ендотелієм, забеспечують протидію агрегації тромбоцитів. При пошкодженні судинної стінки вироблення простациклінів та тромбомодулінів пригнічується, хоча підвищується виділення тромбопластину, фактора активації тромбоцитів та фактора Віллебранда, що сприяють агрегації тромбоцитів та підвищенню зсіданню крові (Кизименко Л. Д. 2002 р.). Тому, в основному, патогенез виникнення антенатальної загибелі плода (АЗП) пов'язаний із гострою або хронічною плацентарною недостатністю, а саме - структурними змінами у стінках судин субплацентарної зони; повною або частковою обтурацією спіральних артерій внаслідок атеросклеротичних змін; зниженням еластичності стінки судин і підвищенням іiі проникності; патологічною незрілістю; порушенням венозного відтоку крові з мужворсинчастого простору; підвищенням тиску в міжворсинчастому просторі; дисбалансом в судинно-тромбоцитарному ланцюзі патогенезу, коагулопатіями, вродженими та набутими тромбофіліями (Воронін К.В. та ін., 2003 р.).

Мета дослідження. Вивчити зміни системи гемостазу у вагітних 3 антенатальною загибеллю плода, оцінити особливості прокоагулянтної, антикоагулянтної та фібринолітичної ланок системи гемостазу у жінок з антенатальною загибеллю плода.

\section{Методологія та методи дослідження.} Для досягнення поставленої мети нами проведено клініко-статистичний аналіз 60 індивідуальних карт вагітних та історії пологів, що поділено на 2 групи. I група (основна $\mathrm{n}=28$ ) - склали жінки $з$ антенатальною загибеллю плода в період з 2016 - 2018 роки, II група (контрольна $\mathrm{n}=32$ ) - жінки з фізіологічним протіканням вагітності та пологів. Обробка даних проводилась на базі Київського міського пологового будинку № 3. Оцінювались такі показниками коагулограми як: прокоагулянтна ланка - протромбіновий індекс 
(ПІ), тромбіновий час (ТЧ), активований парціальний тромбіновий час (АПТЧ), розчинні фібрин мономерні комолекси (РФМК), фібриноген плазми, антикоагулянтна ланка - антитромбін III (ATIII) та протеїн С. Статистична обробка даних виконана з використанням методів варіаційної статистики, кореляційного аналізу, реалізованих в програмі Statistica 6.0 (StatSoft, USA). Достовірність відмінностей середніх значень показників оцінювали за критерієм Манна-Уітні та Ст'юдента. Достовірними вважалися відмінності при $\mathrm{p}<0,05$.

Результати дослідження. Для найбільш інформативного порівняння змін в системі гемостазу, ми розподілили показники коалуограми відповідно до трьох ланок системи гемостазу. Так, оцінку коагуляційної активності проводили за тромбіновим часом (ТЧ), активованим частковим тромбопластиновим часом (АЧТЧ), протромбіновим індексом (ПТІ), вмістом розчинних фібрин-мономерних комплексів (РФМК) та фібриногену. Дані показники відображають послідовність різних етапів згортання крові, а саме: ПТІ - активність зовнішнього шляху згортання, АЧТЧ - інтегральний показник коагуляційного каскаду, ТЧ, РФМК та фі- бриноген - активність заключного етапу згортання (фібриноутворення). Антикоагулянтну ланку гемостазу оцінювали за допомогою антитромбіну III (ATIII) та протеїну C, а фібринолітичну ланку гемостазу вивчали за допомогою оцінки XIIa фактора згортання. Отримані нами показники прокоагулянтної, антикоагулянтної та фібринолізичної ланок системи гемостазу представлені в таблиці 2.

Як видно з таблиці 2, кількість фібриногену - головного субстрату тромбоутворення в плазмі вагітних - збільшено в обох групах. Збільшення рівня фібриногену упродовж вагітності $є$ адаптаційним механізмом до наступних пологів. 3 iншого боку, збільшення рівня і активності інших факторів прокоагулянтної ланки системи гемостазу, поряд з високим вмістом фібриногену, створюють сприятливі умови для внутрішньосудинного тромбоутворення.

Параметри тестів тромбіновий час (ТЧ) та анцистроновий час (АЧ) визначаються рівнем вмісту фібриногену, станом прокоагулянтної ланки системи гемостазу i анти тромбінового потенціалу плазми. Вiдомо, що при гіпер- і гіпофібриногенеміі, наявності продуктів розщеплення фібриногену, появі інгібіторів полімеризації фі-

Таблиця 2. Порівняння показників системи гемостазу у обстежених вагітних

\begin{tabular}{|l|c|c|c|}
\hline \multirow{2}{*}{ Показники гемостазу } & \multicolumn{3}{|c|}{ Параметри системи гемостазу } \\
\cline { 2 - 4 } & Основна група $(\mathbf{n}=\mathbf{2 8})$ & Контрольна група $(\mathbf{n}=\mathbf{3 2})$ & $\mathbf{P}$ \\
\hline$\Phi$, Г/л & $4,36 \pm 0,1$ & $4,56 \pm 0,12$ & PI-II $>0,001$ \\
\hline ТЧ, с & $12 \pm 0,07$ & $11,3 \pm 0,22$ & PI-II $<0,01$ \\
\hline АЧ, с & $32 \pm 2$ & $33,3 \pm 0,63$ & PI-II $>0,05$ \\
\hline АЧТЧ, с & $35 \pm 0,36$ & $36,3 \pm 0,44$ & PI-II $>0,05$ \\
\hline$П I, \%$ & $101,37 \pm 1,1$ & $107,6 \pm 2,26$ & PI-II $<0,01$ \\
\hline РФМК,г/л & $>50,0 \pm 2,2$ & $4,5 \pm 1,7$ & PI-II $<0,001$ \\
\hline ПС,\% & $100,13 \pm 1,33$ & $67,3 \pm 2,41$ & PI-II $<0,001$ \\
\hline АТ-ІІІ, \% & $99,65 \pm 2,13$ & $72,41 \pm 2,53$ & PI-II $<0,001$ \\
\hline
\end{tabular}


брину тест АЧ подовжується. В наших дослідженнях у $38,6 \%$ вагітних параметри АЧ перебували в межах значення «норми» або були дещо зниженими. При значній гіперфібриногенемії, яка спостерігається в обстежених жінок, АЧ, що дорівнює 30+2,0 с або нижче, вказує на виражене скорочення часу зсідання, тобто на «приховану» гіперкоагуляцію, що підтверджується даними тесту ТЧ - у 52,3\% випадків зазначено скорочення часу зсідання, у порівнянні $з$ контролем. Таким чином, показники тестів ТЧ і АЧ свідчать про активацію прокоагулянтної ланки системи гемостазу і підвищену готовність до тромбоутворення при певних умовах (наприклад, виснаження антитромбінової системи і /або пригнічення фібринолізу).

Прискорення процесів зсідання тестах АЧТЧ зумовлено в основному активацією факторів VIII, IX, X, XI, XII. Також можна зазначити, що тест АЧТЧ характеризує не тільки прокоагулянтну ланку системи гемостазу, але і їі антитромбіновий потенціал. Наші дослідження показали, що у 63.6\% вагітних з антенатальною загибеллю плода мало місце вкорочення часу зсідання в тесті АЧТЧ у порівнянні 3 контролем, що вказує на наявність активації зсідання по внутрішньому шляху і зниження антитромбінового резерву.

Середнє значення ПІ у наших дослідженнях становило 107.6+2.26\%. Заслуговує на увагу надмірне збільшення цього показника в окремих випадках. Так, у 68.2\% пацієнтів спостерігається збільшення протромбінового індексу понад 100\%: 115\% і більше зазначено в $31.8 \%$ випадків. Даний тест характеризує зовнішній шлях зсідання. Показники тесту визначаються вмістом і функціональною активністю низки факторів зсідання (II, V, VII, X, фібриногену). Ймовірно, у даній обстежуваній групі найбільш вагомий внесок у показники тесту ПІ відбувається за рахунок Х фактора згортання, це припущення підтверджується результатами наших досліджень. А саме: функціональна активність X фактора згортання крові підвищена і становить у середньому 119.1 $\pm 1.84 \%$, що вірогідно вище показника даного тесту у вагітних з фізіологічним перебігом - 100.5 $\pm 1.1 \%(\mathrm{p}<0.001)$. Причому у $61.4 \%$ вагітних визначається рівень Х фактора згортання крові $>120 \%$.

Рівень вмісту Х фактора згортання крові заслуговує на певну увагу, оскільки він являється ключовим як для внутрішнього, так і для зовнішнього шляхів зсідання крові. Збільшення показників антитромбіну III та вмісту X фактора згортання крові поряд із скороченням часу зсідання в тесті АЧТЧ, указують на надмірну активацію прокоагулянтної ланки системи гемостазу у вагітних з антенатальною загибеллю плода. Це підтверджується наявністю маркерів тромбінеміі.

РФМК $є$ маркерами тромбінемії i ДВ3-синдрому. Наявність їх у плазмі вказує на утворення надлишкової кількості тромбіну в результаті патологічної активації прокоагулянтної ланки системи гемостазу.

Напередодні пологів в усіх обстежених вагітних зазначається зниження антитромбінового резерву системи гемостазу (АТ-III и ПС), виявлення за функціональними тестами. Вміст AT-III коливається

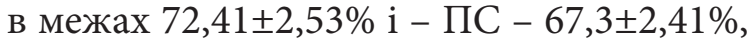
що в обох випадках вірогідно нижче, як порівняти з контролем ( $\mathrm{p}=0,001)$. Слід зазначити, що у 16\% пацієнтів вміст АТ-III дорівнює або нижче 55\%, і у 25\% жінок рівень ПС також дорівнює або нижче 55\%.

Таке значне зниження вмісту природних антикоагулянтів у плазмі вагітних всіх груп напередодні розродження ми розглядаємо як тромбофілічний стан патогенетичну основу розвитку тромбозів і емболії. 
Хоча у виникненні тромботичних ускладнень вирішальне значення відіграють не абсолютні величини активації прокоагулянтної ланки системи гемостазу, а нездатність організму своєчасно і достатньою мірою розвинути відповідну реакцію з боку антитромбінової i/або фібринолізичної ланок системи гемостазу.

При аналізі основних причин виникнення антенатальної загибелі плода, на першому місці виступає передчасне відшарування плаценти на фоні пізнього гестозу $(\mathrm{n}=10)$ або наявність провокуючих факторів пошкодження плаценти, таких як: внутрішньоутробне інфікування $(n=7)$, передчасне старіння плаценти та екстрагенітальна патологія $(\mathrm{n}=11)$. Це вказує на те, що первинною патогенетичною ланкою у виникненні АЗП являються порушення в системі гемостазу.

Висновки. Для вагітних з антенатальною загибеллю плода характерним є підвищення згортуючої активності крові на фоні пригнічення антикоагулянтної та фібринолітичної ланок гемостазу. Загальна схема обстеження системи гемостазу включає показники, які характеризують зовнішній шлях коагуляції (протромбіновий час), внутрішній (активованого парціального тромбінового часу, активований час рекальцифікації) і загальний шлях згортання (тромбіновий час, концентрація фібриногену). Визначення активності антитромбіну III інформує про стан антикоагуляційної системи організму та надає можливість корегувати лікування антикоагулянтними препаратами прямої дії. Кількісне визначення розчинних фібрин - мономерних комплексів (РФМК) дозволяє інформативно чітко охарактеризувати ступінь патологічного процесу внутрішньо-судинного згортання. Активація згортуючого потенціалу крові, як і у вагітних 3 антенатальною загибеллю плода, так і під час фізіологічного перебігу вагітності відбувається за рахунок останньої фази згортання крові - фібриноутворення. Показники коагулограми не можуть повністю відобразити стан гемостазу під час вагітності, тому пошук нових методів ранньої діагностики дисбалансу в системі гемостазу під час вагітності залишається актуальним і на даному етапі.

\section{ЛІТЕРАТУРА}

Міцода, Р. М., \& Садигов, Ю. М. (2015). Клінічна характеристика жінок із завмерлою вагітністю в анамнезі. Здоровье женщины, (10), 150-152.

Чонко, О. Ю., \& Корчинська, О. О. (2018). Особливості системи гемостазу у вагітних із передчасним відшаруванням нормально розташованої плаценти в анамнезі. Проблеми клінічної педіатрії, (2-3), 82-86.

Долгов, В. В., \& Свирин, П. В. (2005). Лабораторная диагностика нарушений гемостаза.

Ridker, P. M., Miletich, J. P., Buring, J. E., Ariyo, A. A., Price, D. T., Manson, J. E., \& Hill, J. A. (1998). Factor V Leiden mutation as a risk factor for recurrent pregnancy loss. Annals of internal medicine, 128(12_Part_1), 1000-1003.

Sanson, B. J., Friedrich, P. W., Simioni, P., Zanardi, S., Huisman, M. V., Girolami, A., .. \& Prins, M. H. (1996). The risk of abortion and stillbirth in antithrombin-, protein C-, and protein S-deficient women. Thrombosis and haemostasis, 75(03), 387-388. 8

Goodman, C. S., Coulam, C. B., Jeyendran, R. S., Acosta, V. A., \& Roussev, R. (2006). Which thrombophilic gene mutations are risk factors for recurrent pregnancy loss? American Journal of Reproductive Immunology, 56(4), 230-236.

Triplett, D. A. (2002). Antiphospholipid antibodies. Archives of pathology \& laboratory medicine, 126(11), 1424-1429.

Кизименко Л. Д. (2002) .Людина. Навч. посібник з анатомії та фізіології. 240

Куликов А. В., \&Шифман Є. М (2016). Інтенсивна терапія гострих порушень гемостазу в акушерстві. Клінічні рекомендації.

Воронін К.В. \& Лоскутова Г.А. (2003) Стан гемодинаміки у вагітних із передчасним відшаруванням плаценти. Вісник наукових досліджень, 1 (30), 22-23.

Ліщук-Якимович, Х. О. (2016). Антифосфоліпідний синдром у практиці лікаря-репродуктолога. Акушерство. Гінекологія. Генетика, (1), 80-82. 


\title{
THE PATHOGENETIC SIGNIFICANCE OF HEMOSTASIS DISORDERS DETECTION FOR THE DIAGNOSTICS AND PREVENTION OF THROMBOTIC COMPLICATIONS IN WOMEN WITH ANTENATAL FETAL DEATH
}

\author{
Kotenok Antonina \\ Assistant of Department of Obstetrics and Gynecology №3, \\ Bogomolets National Medical University, Ukraine \\ Hychka Nazariy \\ Associate Professor of the Department of Obstetrics and Gynecology № 3, \\ Bogomolets National Medical University, Ukraine

\section{Beniuk Vasyil} \\ Professor, MD, Head of the Department of Obstetrics and Gynecology № 3, \\ Bogomolets National Medical University, Ukraine
}

\begin{abstract}
The article summarizes the arguments and counterarguments within the scientific debate on the diagnosis and prevention of disorders in hemostatic blood system in women with antenatal fetal death. The main purpose of this investigation is to study the changes in the hemostatic system in pregnant women with antenatal fetal death, namely to evaluate the features of procoagulant, anticoagulant and fibrinolytic units of the hemostatic system in women with antenatal fetal death. The systematization of literary sources and approaches to the problem of hemostatic disorders in antenatal fetal death provides an opportunity to confirm the importance of this issue, to reasonably evaluate the risks during pregnancy in each particular woman and, first of all, to prevent the occurrence of this complication. This article presents the results of a retrospective study of individual case histories of pregnant women and the case histories of childbirth of women with antenatal fetal death and physiological pregnancy in the period from 2016 to 2018. The relevance of the study of this pathology is that every fifth woman of reproductive age faces a problem such as perinatal loss. In the structure of perinatal losses, antenatal fetal death occupies a special place, which can lead to the development of fetal loss syndrome, DIC, infectious complications in the mother and infertility or subfertility in the future, which in general has a negative impact on the reproductive potential of the nation. In the course of our work we evaluated such coagulogram indicators as: prothrombin index, thrombin time, activated partial thrombin time, soluble fibrin monomer complexes, plasma fibrinogen, antithrombin III, and protein C.

It is established that pregnant women with antenatal fetal death are characterized by increased blood clotting activity against the background of suppression of anticoagulant and fibrinolytic units of hemostasis. Determination of the activity of antithrombin III informs about the state of anticoagulation system of the body and provides an opportunity to adjust the treatment with anticoagulant drugs of direct action. Indicators of coagulogram can't fully reflect the state of hemostasis during pregnancy, so the search for new methods of early diagnosis of imbalance in the system of hemostasis during pregnancy remains relevant at this stage. These studies may be useful for gynecologists, especially in women's counseling, for the formation of risk groups for pregnant women and for preventive measures to prevent antenatal fetal death.
\end{abstract}

Keywords: Antenatal fetal death, hemostasis, endothelium, thrombophilia, coagulation factors.

Manuscript is received 10.08.2019

Manuscripted is accepted 2.09.2019 